\title{
Tables of statutes, cases, decisions and reports
}

\section{European Union Primary Legislation}

Article 2 (ex 2)

Article 3 (ex 3)

Article 6 (ex 3c)

Article 12 (ex 6)

Article 28 (ex 30)

Article 39 (ex 48)

Article 40 (ex 49)

Article 41 (ex 50)

Article 42 (ex 51)

Article 43 (ex 52)

Article 47 (ex 57)

Article 49 (ex 59)

Article 50 (ex 60)

Article 51 (ex 61)

Article 52 (ex 63)

Article 53 (ex 64)

Article 54 (ex 65)

Article 55 (ex 66)

Article 81 (ex 85)

Article 82 (ex 86)

Article 83 (ex 87)

Article 84 (ex 88)

Article 85 (ex 89)

Article 86 (ex 90)

Article 87 (ex 92)

Article 88 (ex 93)

Article 89 (ex 94)

Article 141 (ex 119)
$8,84,90,120$
$1,83,111,175,205,207,214$
94
$83,86,88,103,130$
100,104

83-84, 85, 86, 87, 88-89, 90, 91, 94, 95-101, $103,104,120,138,178,211,214$

86,88

86,88

$34,86,88$

$83,84-85,90,99,214$

169

$83,85,86,87,88-89,90,99,101-102,104,130,169,214$

$85,86,88-89,169$

86,88

86,88

86,88

86,88

$86,88,169$

$18,85,94,97,98,101,103,109,111,112-115,117-119$, 121-149, 151, 155, 210, 212, 213, 214, 217, 219 $85,94,97,101,103,111,115-117$, 119-120, 122, 129, 130, 133, 135, $136,139,152,210,214,217$

111,215

$111,115,138$

111

111

83 
Article 149 (ex 126)

Article 151 (ex 128) 167, 175, 214

Article 192 (ex 138b)

Article 208 (ex 152)

Article 211 (ex 155)

Article 234 (ex 177)

$16,67,81,83,86,204$

Article 251 (ex 189b)

Article 308 (ex 235)

Article 53 EEA

Declaration 29, Treaty of Amsterdam amending the Treaty on

European Union, the Treaties establishing the European

Communities and certain related Acts, (1997)

$15,17,19,33,34,73$, 102, 103, 104, 140, 150, 154, 173-176, 177, 178, $180,183,184,185-186$, 189, 196, 209, 212

\section{European Union Secondary Legislation}

Directive 64/221, OJ Spec. Ed. 117

84,85

Directive 68/360, OJ Spec. Ed. 485

Directive 85/337, OJ L 175, 5/7/85

Directive 89/104, OJ L 40 21/12/88

Directive $89 / 552$, as amended by Directive 97/36/EC

Directive 92/43, OJ L 206, 22/7/92

Regulation 17/62 [1962], OJ L 13

$111,114,115,116$

Regulation 1612/68

84,86

Regulation 1251/70

Regulation No. 870/95, Block Exemption - Liner Shipping Agreements

Regulation No. 1475/95, Block Exemption - Motor Vehicle Distribution

Agreements

\section{Decisions of the European Court of Justice and Court of First Instance}

26/62, Van Gend en Loos $v$. Nederlandse Administratie der Belastingen, [1963] ECR I

56 and 58/64, Consten and Grundig $v$. Commission [1966] ECR 299

56/65, Société Technoque Minière $v$. Maschinenbau Ulm [1966] ECR $235 \quad 113$

152/73, Sotgiu $v$. Deutsche Bundespost [1974] ECR 153

155/73, Italy $v$. Sacchi [1974] ECR $409 \quad 169$

167/73, Commission $v$. French Republic [1974] ECR 359

2/74, Reyners $v$. Belgian State [1974] ECR $631 \quad 85$

8/74, Procureur du Roi $v$. Dassonville [1974] ECR 837 
36/74, Walrave and Koch $v$. Association Union Cycliste

Internationale [1974] ECR 1405

13/76, Donà v. Mantero [1976] ECR 1333
$7,8-9,12,19,27,63,73,77,80$, $84,85-87,90-91,99,105,160$ $7,8-9,12,19,27,63,73,77,80$, $87-89,90-91,98,99,105,160$

120/78, Rewe-Zentral AG $v$. Bundesmonopolverwaltung für

Branntwein (Cassis de Dijon) [1979] ECR 649

52/79, Procureur du Roi $v$. Debauve [1980] ECR 833

262/81, Coditel $v$. Ciné Vog Films SA [1982] ECR 3381

66/85, Lawrie-Blum $v$. Land Baden-Württemberg [1986]

ECR 2121

222/86, UNECTEF $v$. Heylens [1987] ECR 4097

$7,9,27,63,73,77$ 80, 89-90, 90-91

262/88, Barber $v$. Guardian Royal Exchange Assurance Group

[1990] ECR I-1889

260/89, ERT $v$. DEP [1991] ECR I-2925

77

169

169

99

106/91, Ramrath $v$. Ministre de la Justice [1992] ECR I-3351

$148 / 91$, Vereniging Veronica $v$. Commissariaat voor de Media

[1993] ECR I-487

169

267-268/91, Keck and Mithouard [1993]

ECR I-6097

19/92, Kraus $v$. Land Baden-Württemberg [1993] ECR I-1663

250/92, Gøttrup-Klim Grovvareforeninger and Others [1994]

ECR. I-5641

23/93, TV10 SA $v$. Commissariaat voor de Media [1994]

ECR I-4795

100,104

99

133,215

384/93, Alpine Investments BV v. Minister van Financiën [1995]

ECR I-1141

415/93, Union Royale Belge Sociétés de Football Association

and Others $v$. Bosman [1995] ECR I-4291

$1,3,7,9,12,14,15,19,27,33$, $61-65,73,75,76,77,80,84$, 91-101, 104, 106, 138, 139, 140,

$145,149,160,173,209,214,222-242$

T-528/93, T-542/93, T-543/93 and T-546/93, Métropole

Télévision SA $v$. Commission [1996] ECR II-649

51/96-191/97, Deliège $v$. Asbl Ligue Francophone

de Judo and Others [2000] ECR I-2549

106/96, UK $v$. Commission ECR I-02729

19, 73, 80, 101-105, $106,177,197,209-210$

72,218

176/96, Jyri Lehtonen and Castors Canada Dry Namur-Braine $v$. Fédération

Royale des Sociétés de Basketball and Ligue Belge-Belgische

Liga [2000] ECR I-2681

19, 73, 80, 101-105, 106, 197, 209-210

246/98, Tiborbalog $v$. Royal Charleroi Sporting (case withdrawn)

318/00, Bacardi-Martini et Cellier des Dauphins (pending)

98,149

438/00, Deutscher Handballbund $v$. Maros Kolpak (pending)

131

206/01, Arsenal Football Club plc $v$. Matthew Reed (unreported) 


\section{European Commission Competition Decisions}

Film Purchases by German Television Stations [1989] OJ L 248

$\begin{array}{ll}\text { Screensport [1991] OJ L } 63 & 127\end{array}$

Dunlop Slazenger International [1992] OJ L 131

Distribution of Package Tours During the 1990 World Cup [1992] OJ L 326128

$\begin{array}{ll}\text { EBU-Eurovision System [1993] OJ L } 179 & 127\end{array}$

$\begin{array}{ll}\text { Tretorn [1994] OJ L } 378 & 131\end{array}$

$\begin{array}{ll}1998 \text { Football World Cup [2000] OJ L 5 } & 130\end{array}$

EBU-Eurovision System [2000] OJ L 151 127

UEFA's Broadcasting Regulations [2001] OJ L 171

\section{European Commission Competition Cases}

BBC, BSB and Football Association [1993] OJ C $94 \quad 126$

Commission Notice [1996] OJ C $138 \quad 131$

KNVB/Sport [1996] OJ C $228 \quad 126$

Commission Notice [1997] OJ C $372 \quad 116$

DN: IP/98/355, 'The Commission Conditionally Approves Sponsorship

Between the Danish Tennis Federation and Its Tennis Ball Suppliers', $15 / 04 / 98$

DFB [1999] OJ C $6 \quad 123$

Project Gandalf [1999] OJ C $70 \quad 133$

$\begin{array}{ll}\text { UEFA [1999] OJ C } 99 & 123\end{array}$

DN: IP/99/133, 'Commission Debates Application of Its Competition

Rules to Sport', 24/02/99 18, 151-152, 210

DN: IP/99/434, 'Commission Opens Formal Proceedings into Formula

One and Other International Motor Racing Series', 30/6/99 135-136

DN: IP/99/782, 'Commission Launches Formal Proceedings on FIFA Rules

Governing Players' Agents', 21/10/99

DN: IP/99/965, 'Limits to Application of Treaty Competition Rules to Sport:

Commission Gives Clear Signal', 09/12/99

DN: IP/00/372, 'Commission Ready to Lift Immunity from Fines to

Telefónica Media and Sogecable in Spanish Football Rights Case', $12 / 04 / 00$

DN: IP/00/1352, 'Commission Withdraws Threat of Fines against

Telefónica Media and Sogecable, but Pursues Examination of Their Joint Football Rights', 23/11/00

DN: IP/01/120, 'Commission Welcomes Progress towards Resolving the

Long- running FIA/Formula One Case', 26/01/01

Letter from Mario Monti to Joseph S. Blatter, 5/03/01 D/000258 148

DN: IP/01/583, 'Commission Clears UEFA's New Broadcasting

Regulations', 20/04/01

DN: IP/01/599, 'Commission Does not Object to Subsidies for French Professional Sports Clubs', 25/04/01

Notice published pursuant to Article 19(3) of Council Regulation No. 17 concerning cases COMP/35.163 - Notification of FIA Regulations, COMP/36.638 - Notification by FIA/FOA of Agreements relating to the 
FIA Formula One World Championship, COMP/36.776 - GTR/FIA and others (2001/C169/03), 13/06/01

DN: IP/01/1043, 'Commission Opens Proceedings against UEFA's Selling of TV Rights to UEFA Champions League', 20/07/01

$\mathrm{DN}$ : IP/01/1523, 'Commission Closes Its Investigation into Formula One and other Four-wheel Motor Sports', 30/10/01

DN: IP/02/806, 'Commission Welcomes UEFA's New Policy for Selling the Media Rights to the Champions League', 03/06/02

DN: IP/02/824, 'Commission Closes Investigations into FIFA Regulations on International Football Transfers', 05/06/02

DN: IP/02/942, 'Commission Closes Investigation into UEFA Rule on Multiple Ownership of Football Clubs', 27/06/02

DN: IP/02/1211, 'Commission Rejects Complaint against International Olympic Committee by Swimmers Banned from Competitions for Doping', 09/08/02

ENIC/UEFA [2002] Case COMP/37 806

\section{European Commission Papers}

COM (84) 300, 'On the Establishment of the Common Market Broadcasting, especially by Satellite and Cable', 1984

COM (84) 446 Final, 'A People's Europe, Reports from the Ad Hoc

Committee'

'Development and Prospects for Community Activity in the Field of Sport', Commission Staff Working Paper, Directorate General X, 29/09/98

$15,178-180,196,212$

'The European Model of Sport', Consultation Document of DG X', 1998

$15,180-183,196,212$

COM (1999) 644, 'Report from the Commission to the European

Council with a View to Safeguarding Sports Structures and

Maintaining the Social Significance of Sport Within the Community

Framework: The Helsinki Report on Sport', 1/12/99 16, 145, 146, 187-189,

$197,207,209,218,219,243-250$

COM (2000) 582 Final, 'Proposal for a Council Regulation on the Implementation of the Rules on Competition Laid Down in Articles 81 and 82 of the Treaty and Amending Regulations' (EEC) No. 1017/68, (EEC) No. 2988/74, (EEC) No. 4056/86 and (EEC) No. 3975/87. ('Regulation Implementing Articles 81 and 82 of the Treaty'), 27/09/00 $18,109,115,219$

COM (2001) 584 Final, 'Proposal for a Decision of the European Parliament and of the Council Establishing the European Year of Education through Sport', (2004), 16/10/01

\section{European Parliament Resolutions and Reports}

A-0415/88, 'Report for the Committee on Legal Affairs and Citizen's Rights, on the Freedom of Movement of Professional Footballers in the Community', 03/89, Rapporteur: J. Van Raay 
B3-1909/90, Motion for a Resolution of 8/11/90 on the 'Protection of

Popular Sporting Traditions in Europe', Rapporteur: Mrs Ewing

B3-0862/91, Motion for a Resolution of 10/6/91 on the 'Need to

Reappraise the EC's Sports Policy', Rapporteur: Mrs Banotti

B3-1512/91, Motion for a Resolution of 15/10/91 on 'Professional

Boxing', Rapporteur: Mr Díaz

B3-1725/91, Motion for a Resolution of 12/11/91 on a 'Common

Logo for Athletes from the 12 Member States Taking Part in the

Next Olympic Games', Rapporteur: Mrs Muscardini

B3-0456/92, Motion for a Resolution of 15/4/92 on 'Legislation to Outlaw

Symbols Which Incite Violence in Sport', Rapporteur: Mr Abeilhe et al

B3-0714/92, Motion for a Resolution of 1/6/92 on the 'Safety of Sports

Installations', Rapporteur: Mrs Muscardini

A3-0326/94, Part A (27/4/94) Part B (29/4/94), 'Report on the European

Community and Sport', Rapporteur: Mrs J. Larive 15, 137, 164-166, 178, 196

A4-0197/97, 'Report on the Role of the European Union in the Field

of Sport', Rapporteur: Mrs D. Pack, 28/5/97

$15,167-169,196$

A5-0208/2000, 'Report on the Commission Report to the European

Council with a View to Safeguarding Current Sports Structures and

Maintaining the Social Function of Sport within the Community

Framework: The Helsinki Report on Sport', the Mennea report, 18/07/00

PE 286.761, 'Draft Opinion of the Committee on Culture, Youth,

Education, the Media and Sport for the Committee on Constitutional

Affairs on the Treaty of Nice and the Future of the European Union',

Draftsman: Barbara O'Toole, 23/03/01

A5-0133/2002, 'Report on the Division of Competences Between the

European Union and the Member States' (2001/2024(INI)), Committee

on Constitutional Affairs, Rapporteur: Alain Lamassoure, pp. 18-19, $24 / 04 / 02$

\section{Presidency Publications and Miscellaneous Member State Papers}

OJ No. C-329, Council Resolution of 3/12/90 on Community Action to Combat the Use of Drugs, Including the Abuse of Medicinal Products, Particularly in Sport

Chamberlain, P. (1998), UK Presidency of the European Union, Troika Meeting of EU Sports Ministers, Twickenham Stadium, 2 April 1998. Sport and Recreation Division, 8/4/98

British Presidency Conclusions (15-16/6/98), Cardiff European Council

Austrian Presidency Conclusions (11-12/12/98), The Vienna European Council Presidency Conclusions

German Presidency Conclusions (31/5/99-2/6/99), 'Conclusions of the

German European Council Presidency on the Occasion of the Informal

Meeting of the Sport Ministers of the European Union - "the

Paderborn Conclusion",

$15,185-186$

Finnish Ministry of Education (1999), 'Priorities: Ministry of Education',

Finnish EU Presidency website 
Finnish Presidency Conclusions (18-20/10/99), Sports Directors Meeting, Conclusions of the Presidency

Conclusions of the Informal Council of Ministers of Sport of the European Union, Lisbon (10/5/00)

Portuguese Presidency Conclusions (19-20/6/00), Presidency Conclusions, Santa Maria da Feira European Council

'Declaration on the Specific Characteristics of Sport and Its Social Function in Europe, of which Account Should Be Taken in Implementing Common Policies', Presidency Conclusions, Nice European Council Meeting, 7, 8, 9 December 2000 $15,19,34,70,124,143,146-147,154,191-194,195,209$

\section{Cases before the National Courts}

Order of September 2, 1994, B 6-747000-A105/92, WuW/EBkartA 2682

Wilander $v$. Tobin [1997] Eu LR 265

122

Edwards $v$. British Athletics Federation and International Amateur Athletics Federation [1997] Eu LR 721

Stevenage Borough FC Ltd $v$. Football League Ltd [1997] 9 Admin LR 109 118

Judgement of the Restrictive Practices Court (in England and Wales), July 28, 1999 in the matter of the Restrictive Trade Practices Act 1976 and in the matter of an agreement between the Football Association Premier League Limited and the Football Association Limited and their respective member clubs and in the matter of an agreement relating to the supply of services consisting in the broadcasting on television of such matches. The Act has since been replaced by the 1998 Competition Act

Carlton Communications PLC and Granada Media plc $v$. Football League [2002] EWHC 1650, QBD Commercial Court, Langley J. 1 August

\section{Miscellaneous publications}

CAS 98/200 AEK Athens and Slavia Prague $v$. UEFA, 20/08/99, Lausanne, Switzerland

Opinion of the Committee of the Regions on 'The European Model of Sport', OJ C [1999] 374, 23/12/99

Joint FIFA / UEFA Negotiation Document (International Transfer of Players). Available at www.uefa.com, 10/01

10th European Sports Forum. Framework document for working group discussions on the implementation of the Nice Declaration. Non-paper, 17/18 October 2001

10th European Sports Forum. Conclusions of the working group on the follow up to the Nice Declaration, 17/18 October 2001 
Richard Parrish - 9781526137661 Downloaded from manchesterhive.com at 04/26/2023 09:15:50AM via free access 